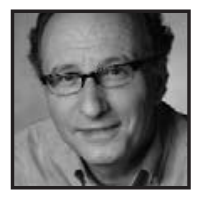

\title{
Commentary:
}

\section{The Intellectual Properties of Literacy}

\author{
John Willinsky, Stanford University
}

\begin{abstract}
This paper presents the case for considering literacy and learning as possessing a distinct set of intellectual properties that set apart literacy in the context of learning from other sorts of intellectual property that we commonly associate with commercial endeavors. It argues for the value of thinking about intellectual properties as a means of preparing the young both for economic life in the age of information, and for appreciating the importance of protecting the state of learning as a special sphere of intellectual activity and thus intellectual property. The example is given of how students' own contribution of intellectual properties, as a result of their learning, can add something of value to their communities.
\end{abstract}

f I had to identify a single thread that has long connected aspects of my teaching, writing, and literacy outside of school, it would have to do with how words are made public and leave their mark on the world. For example, I find myself drawn to and fascinated by how words sit on a piece of paper or the page of a book, how they mark walls and form signs. I am a fan of graphic design and curious about typography. Given the work of a great photographer like Walker Evans, I am drawn above all to his pictures of store signs from the 1930s, often hand-painted and overwhelming the storefronts. ${ }^{1}$ The words just seem so clear and present in their meaning and intent, in how they have been formed and set out for all to see; the sign-filled photographs seem so much more direct and comprehensible than Evans' more famous photographs of poor sharecroppers in the brilliantly evocative Let Us Now Praise Famous Men (Agee \& Evans, 1960), that he did with James Agee. ${ }^{2}$ 
More generally, I hold with how words travel far and wide through acts of publishing. And given the sheer scale and scope of book publishing, I fall back, as many a reader gratefully does, on book reviews as a way of almost keeping pace with themes and authors of interest to me. Here, then, is the center of literate culture for me. No days without book reviews, I say, and little writing without review and reference to others' works, as you have already seen, having read this far.

This fascination with what is made public out of otherwise seemingly private words has led me in the past to teach children the history of publishing from oral poetry through illuminated manuscripts down to dot-matrix books (Willinsky, 1985). It has had me, more recently, helping others create software that thousands of scholarly journals now use to move a journal from Nairobi that reached a hundred readers in print to now reach many times that online (Willinsky, 2005). But then, away from the screen, I am still fascinated by the endlessly inventive print forms that McSweeney's magazine takes, different with each issue, from artbook to junk mail, while my little house continues to pile up with a book-by-book record of a life of reading. ${ }^{3}$

Yet this commentary on literacy is not the place to set out a few of my favorite things. It is an opportunity to set something right, to introduce what has been missing from my work and teaching on literacy. It seems to me now that I have largely overlooked one of the central ideas underwriting literate activity, the very thing, in fact, that makes reading and writing more than a school-child's exercise and fully a part of the world of getting and spending.

What I want to consider here is the largely absent place of intellectual property in my learning landscape, at least until recently, and what this idea has to offer in learning about literacy. We teach about reading and writing without letting the young in on how literacy makes its mark by virtue of this concept. This sense of writing as creating property gives words their legal and economic claim on the world. Intellectual property rights govern the making public of language in this way. IP rights, as they are known, typically take the form of copyright in the case of writing. And such rights not only concern who can sell and profit from a work, but also who can be identified with the work, and have a say in how that work is distributed and shared, whether for money or on some other basis.

Still you may want to politely interject, "What does this have to do with teaching children to read and write, to having them care for the word?" That this is not immediately clear is, well, exactly my point. For certainly, it had never occurred to 
me either that the copyright notice, tucked away in small print behind the title page, was connected to the teaching of literacy. Now it seems perfectly clear to me that if you care about literacy, you are already drawing some inspiration, however unconsciously, from how words have this status as property, and how this literate realm then forms the ground beneath one's feet, providing a place to stand and call one's own.

While there is not room here to properly consider how words took on this legal status as property, it was part of a long historical process involving queens and kings, courts and pirates, bankrupt authors and wealthy publishers (as well as vice versa). Perhaps the one historical moment to be noted is that intellectual property is generally considered to have been launched in English law with the Statute of Anne, 1710, otherwise known as An Act for the Encouragement of Learning. ${ }^{4}$ If intellectual property had its start to encourage learning, then surely it is a good match for any act of teaching.

Yet I have to admit that I only began to think about how dependent literacy is on the concept of intellectual property after trying to increase the public availability of a specific body of such property. It was not students' poetry or one of their stories this time. The work I wanted to make more accessible was none other than the scholarship and research that was being done by my colleagues around the world in the service of, I think it fair to say, the public good and people everywhere.

The concept of intellectual property was, of course, critical to why this public good could not be more widely shared. Where I ran into trouble was in trying to say to the world, in effect, "Here, I want to share with you, whether you are teachers, parents or librarians, what I discovered in my research into what children are learning about reading." And what I learned to say, as a result of intellectual property law was, "Oh, wait, I cannot share this work with you because I have transferred all of my intellectual property rights to publishers who have, well within their rights, forbidden me to publicly share this work."

I will not take the time here to go into this important educational issue of access to knowledge, except to say that the academic community is slowly making progress in opening research and scholarship to public view (Willinsky, 2006). In the process, I have been struck by how learning inspires the creation of a special sort of intellectual property. This does not mean that I simply want to sell student work to the public as a profit-sharing incentive for learning, despite Samuel Johnson's (n.d.) counsel that "no man but a blockhead ever wrote, except for money." It means rethinking how we value learning in schools, because this concept of intellectual 
property speaks to how we value things. I can see that this is a tricky idea to express clearly. To put it another way, when the act of learning leads to the production of the intellectual property, which is not always the case as I will explain below, the value of that property is closely tied to the learning it encourages in others, that is, in what I can learn from the fruits of your learning.

Now I am referring to learning here in a double sense. I see it involving "the whining schoolboy, with his satchel / And shining morning face, creeping like snail / Unwillingly to school," as Shakespeare (1599-1600 / 1977) had it, and I see it involving the learned scholar - if not possessing "the scholar's melancholy, which is emulation," to return to Jaques in As You Like It. After all, the learning of both student and scholar is closely connected in an economic sense, as their learning is often publicly sponsored by the state.

This act of sponsorship means, to my way of thinking, that the resulting work, whether an assignment or research paper, constitutes a different order of intellectual property than, say, John Updike's (2009) posthumously published volume of poems. Let me say a little more about that. After a lifetime of reading and teaching Updike, his final poems gave me as serious pause as anything I have read. My and many others' appreciation of his writing permitted him to live and thrive by his particular mastery of this craft in poetry, novel, short story and review. Updike's work also reflects a good deal of learning, and I would use his clever poems about scientific phenomenon, for example, in my classes. But Updike's example is not the only way that intellectual property works. We might say that literacy has other intellectual properties.

For example, my writing on Updike here represents intellectual property of a different order. It is sponsored by my employer, which as a tax-exempt institution, reflects something of a publicly sponsored gift (albeit of far lesser quality than Updike's least scribble). It is a gift of public patronage which the academic community tries its best to exercise responsibly (through peer-review for example, if not in this invited case, in many others). So learning itself is not the key issue but how that learning is sponsored, whether directly through the sale of the resulting work or through the support of an educational institution. Remove the direct dependency on the sale of the work from our thinking about intellectual property, and you are left with a sense of its public contribution as the full measure of its value. To return to the children in the classroom, they, too, are part of a patronized educational setting, and thus they, too, can engage in creating intellectual property in which the value of that property is established (and experienced) in its contribution to the learning of others. 
You may recall the great writing teachers Jane Hansen and Donald Graves in the 1980s, describing the value of having an "author chair" in the classroom, where a child would sit and talk to the class about his or her work, as an author (Hansen, 1985). It was just the sort of make-believe, with serious intent, that is always rewarding to play out with the young. The children in those classes inspired by Jane and Donald wrote magnificently, draft after draft, and were rightly proud of the resulting work which they shared through their books.

What did not cross my mind, in the inspiration that I drew from their work, was that, in a very real and legal sense, we did not need magic chairs to draw the connection between child and writer. As a point of law, the students working on their hand-written books already had a claim on being authors in possession of the very same intellectual property rights by which adult authors live or have to pursue day jobs. ${ }^{5}$ The students were only missing one thing. They had no sense of those rights, even as they were able to discover the value of such properties, as reflected, for example, in the beaming faces of their grandparents as they read these books.

What we have today, even with the eclipsing of the writing process movement in the face of high-stakes testing, is the following situation with regard to the child and intellectual property: (1) The child creates intellectual property in school on occasion. (2) The child learns little if anything about intellectual property in school. (3) The child trades and traffics in intellectual property outside of school, by sharing games, music, and much more, with still only a rough understanding of what is being hacked, ripped, and burned. (4) And finally the child lives in, and will come to work in, a world in which intellectual property fuels knowledge-based economies, and is as critical to global competitiveness among nations as it is to the struggling songwriter with a MySpace site.

My claim is that we would do well, as educators, to have the students both experience and learn about how intellectual property works both within and outside of educational settings. They need to see how literacy is part of the circulation of learning that they are already part of within educational settings, as well as part of the economy into which they are going to graduate.

Now the lines are not neatly or finely drawn between which intellectual properties are going to be freely shared and which are charging an admission price. Yet there is a growing public sphere of freely shared learning materials to which one can point. These materials are taking advantage of the Internet to distribute intellectual properties of creative and educational value, whether one looks at the Creative 
Commons movement, the Open Access movement, Open Educational Resources, or Wikipedia. ${ }^{6}$ These burgeoning developments provide a quick course in how inspired people have become in directing their literacy toward sharing what they have created and have learned. They involve a deliberate rethinking of intellectual property that is focused on the learning value rather than the price markup.

What children will learn - as they work out ideas on paper, tell a story, gather and analyze some information about their community, construct a review, or otherwise put something together that proves of value to others-is that the value of the resulting intellectual properties depends (once you move beyond your grandparents) on the quality and care, as well as the imagination and flare, that they bring to such work. They will learn to ask themselves, "Who would value such work and howcan I increase that value?"

When I recapitulated the history of publishing with those elementary school students, we took our oral poetry, our illuminated manuscripts, our posted broadsides out into hallways of the school as an act of "publishing" the work. While we might have taught the rest of the school more about how these works fit into the history of publishing, we did learn about what it meant to make work public, and how to stop groups of students in a hallway with a poem writ large and posted in an unexpected spot.

For children to discover their ability to create intellectual property of this sort, as a result of their learning, would go a long way in tempering the lessons that they are otherwise learning when they are asked to demonstrate their literacy by bubble-filling multiple-choice tests. The work that goes into the test has little value to others or themselves, outside of the score they achieve, just as the reading "passages," are otherwise removed from the world of what people read. The tests may indicate a certain capacity and readiness, but my argument is, of course, that students are also in a position to give an account of their literacy that is directly reflected in the production of intellectual properties that can stand as a public good.

In terms of that accountability, consider how the schoolhouse may well represent the most intense and concentrated center of learning in a given community. To take but one example of how that capacity can be put to good use, Bill Munn and Rob Lucas, teacher and former student, have worked with high school history students in assembling a Wiki recording of the history of their town Marion, Indiana. ${ }^{7}$ The students have honed their literacy skills in capturing and representing aspects of the town's history, whether with an entry on James Dean and the "curse of the car," as one 
student put it, or in conducting an interview with Jim Perkins, who told the student about the unsuccessful efforts in the 1950s to integrate the town's public pool, as part of a long-standing civil rights struggle.

The growing historical Web site which students and teacher have created provides shining examples of how learning and labor can go into creating properties of lasting value to that community and the world at large (especially given the reach of James Dean). It forms a way for students and teachers to consider the different ways in which intellectual property operates, ensuring a recognition of and respect for their work that teaches them about the public value of learning. Such examples also enable students to explore how decisions are made about whether to commercialize such properties, and help the students to see how this concept of intellectual property is what gives ideas their standing in the world.

I realize that the value of literacy and what it makes of the world is complicated enough, and introducing this concept of intellectual property may only seem to further confuse matters. Yet for me, the complexities and controversies that surround intellectual property can demonstrate to students the import of this form of property to our lives. At the very least, I think it is worth introducing this idea of intellectual property into the conversation with students, when it comes to talking about the value of their and others' work, as it is freely shared or sold, as authorship is claimed, as we acknowledge or seek permission to use the work of others. Intellectual property is what grounds literacy, legally investing it with a value that I think students can begin to experience long before they have written their last literacy test. The complexities associated with this property idea also suggest why it needs to come up repeatedly over the course of the student's career. Only then, with experience and reflection, will the intellectual properties of literacy —as a right, a value, and an opportunity - contribute to their sense of how reading and writing matter. 


\section{Notes}

1. For example, see Walker Evans' 1930s photograph of New Orleans, http://tinyurl.com/oo7sv6.

2. For an example of Evans' work in the book, see http://www.brusselstribunal.org/Meyer/Crisis_bestanden/image029.jpg.

3. To learn more about McSweeney's, a quarterly magazine, see http://www.mcsweeneys.net/

4. For more information, see: http://en.wikipedia.org/wiki/Statute_of_Anne

5. When I turned to Amazon to have a look at Donald Graves' books, there was a Special Offers and Product Promotions on the same page as his book which read, "Want to make your book available for sale on Amazon.com and other channels? Self-publish and sell your book on-demand through BookSurge, a member of the Amazon group of companies." Here was the intellectual property aspect of the amateur writer recognized and capitalized upon.

6. See Creative Commons http://creativecommons.org/; Open Access (Willinsky, 2006); and Open Educational Resources http://www.oercommons.org/.

7. See Wiki Marion: http://wikimarion.org/.

\section{References}

Agee, J., \& Evans, W. (1960). Let us now praise famous men. Boston: Houghton Mifflin.

Hansen, J. (1985). "The Author's Chair," Language Arts, 60, 176-183.

Johnson, S. (n.d.). "Quotes on Writing". Retrieved November 9, 2009, from http://www. samueljohnson.com/writing.html

Shakespeare,W.(1599-1600 / 1977). As you like it. New York: Modern Language Association of America.
Updike, J. (2009). Endpoint and other poems. New York: Knopf.

Willinsky, J. (1985). "To Publish and Publish and Publish," Language Arts, 62, 619-623.

Willinsky, J. (2005). “Open Journal Systems: An Example of Open Source Software for Journal Management and Publishing," Library Hi Tech, 23(4).

Willinsky, J. (2006). The access principle: The case for open access to research and scholarship. Cambridge, MA: MIT Press. 


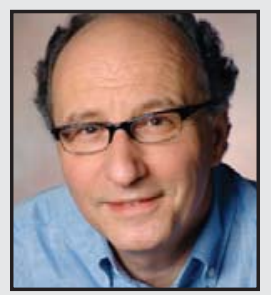

John Willinsky is Khosla Family Professor of Education at Stanford University and director of the Public Knowledge Project at Stanford, University of British Columbia, and Simon Fraser University. Much of his work, including his book, The Access Principle: The Case for Open Access to Research and Scholarship (MIT Press, 2006), winner of two outstanding book awards, as well as PKP's award-winning open source software for journals and conferences, is free to download through the project's Web site (http://pkp.sfu.ca).

\section{LINK TO:}

http://pkp.sfu.ca 